\title{
Airway pressure release ventilation: A neonatal case series and review of current pediatric practice
}

\author{
Shikha Gupta MD1, Vinay Joshi MD², Preetha Joshi MD², Shelley Monkman RRT ${ }^{1,2}$, \\ Kelly Vallaincourt RRT ${ }^{1}$, Karen Choong MB BCh MSc ${ }^{1,2,3,4}$
}

S Gupta, V Joshi, P Joshi, S Monkman, K Vallaincourt, K Choong. Airway pressure release ventilation: A neonatal case series and review of current pediatric practice. Can Respir J 2013;20(5): e86-e91.

BACKGROUND: The use of airway pressure release ventilation (APRV) in very low birth weight infants is limited.

OBJECTIVE: To report the authors' institutional experience and to review the current literature regarding the use of APRV in pediatric populations. METHODS: Neonates < $1500 \mathrm{~g}$ ventilated using APRV from 2005 to 2006 at McMaster Children's Hospital (Hamilton, Ontario) were retrospectively reviewed. Publications describing APRV in children from 1987 to 2011 were reviewed.

RESULTS: Five infants, 24 to 28 weeks' gestational age, were ventilated using APRV. Indications for APRV were refractory hypoxemia $(n=3)$, ventilatory dyssynchrony $(n=1)$ and minimizing sedatives $(n=1)$. All infants appeared to tolerate APRV well with no recorded adverse events. Current pediatric evidence regarding APRV is primarily observational. Published experience reveals that APRV settings in pediatrics often approximate those used in adults, thus deviating from the original guidelines recommended in children. Clinical outcomes, such as oxygenation, ventilation and sedation requirements, are inconsistent.

CONCLUSIONS: APRV is primarily used as a rescue ventilation mode in children. Neonatal evidence is limited; however, the present study indicates that APRV is feasible in very low birth weight infants. There are unique considerations when applying this mode in small infants. Further research is necessary to confirm whether APRV is a safe and effective ventilation strategy in this population.

Key Words: Airway pressure release ventilation; Pediatrics; Very low birth weight infant

Drogressive advances in neonatology have improved the survival of very low birth weight (VLBW) infants; however, the prevalence of neonatal chronic lung disease (CLD) remains high, affecting 23\% of these infants. Hence, the pursuit of optimum ventilation strategies that improve morbidity and, potentially, mortality in this population is of great interest. The best lung-protection ventilation strategy to reduce the incidence of CLD in preterm infants, however, remains unclear (1-3).

Originally described by Stock et al (4) in 1987, airway pressure release ventilation (APRV) is a time-triggered, pressure-limited mode that provides continuous distending airway pressure with an intermittent pressure-release phase (5). These two levels of airway pressure are referred to as $\mathrm{P}_{\text {high }}$ and $\mathrm{P}_{\text {low }}$, respectively, and are each time cycled $\left(T_{\text {high }}\right.$ and $\left.T_{\text {low }}\right)(6)$. The proposed advantages of APRV over conventional mechanical ventilation are that it optimizes alveolar recruitment and ventilation-perfusion matching, enables spontaneous respiratory effort throughout the ventilator cycle, improves cardiac filling and, subsequently, end-organ perfusion, and reduces requirements for sedation and neuromuscular blockade (5,7-13). APRV has, therefore, been suggested as both a lung-protective as well as rescue ventilation strategy in patients with refractory hypoxemia. While studies involving adults have yet to demonstrate the superiority of

\section{La ventilation avec relâchement de pression : une série de cas néonatals et une analyse de la pratique actuelle en pédiatrie}

HISTORIQUE : L'utilisation de la ventilation avec relâchement de pression (VRP) est limitée.

OBJECTIF : Rendre compte de l'expérience des auteurs en établissement et analyser les publications récentes sur l'utilisation de la VRP au sein des populations d'âge pédiatrique.

MÉTHODOLOGIE : Les chercheurs ont procédé à l'analyse rétrospective des nouveau-nés de moins de $1500 \mathrm{~g}$ sous VRP au McMaster Children's Hospital de Hamilton, en Ontario, entre 2005 et 2006. Ils ont analysé les publications de 1987 à 2011 dans lesquelles on décrivait la VRP chez les enfants.

RÉSULTATS : Cinq nourrissons de 24 à 28 semaines d'âge gestationnel ont subi une VRP. Les indications de VRP étaient une hypoxémie réfractaire $(n=3)$, une dyssynchronie ventilatoire $(n=1)$ et une diminution des sédatifs $(n=1)$. Tous les nourrissons semblaient bien tolérer la VRP, qui n'a suscité aucun signalement d'effet indésirable. Les données probantes à jour en pédiatrie au sujet de la VRP sont surtout tirées d'observations. Selon les publications, les réglages de la VRP en pédiatrie avoisinent souvent ceux des adultes, ce qui diffère des lignes directrices originales recommandées chez les enfants. Les issues cliniques, telles que les besoins d'oxygénation, de ventilation et de sédatifs, ne sont pas concluantes.

CONCLUSIONS : La VRP est surtout utilisée comme mode ventilatoire de secours chez les enfants. Les données sont limitées en néonatologie, mais selon la présente étude, la VRP est faisable chez les nourrissons de très petit poids à la naissance. Il faut tenir compte de considérations particulières pour l'utiliser chez les petits nourrissons. D'autres recherches s'imposent pour confirmer si la VRP est une stratégie ventilatoire sécuritaire et efficace au sein de cette population.

APRV over conventional mechanical ventilation (14), there continues to be great interest in this mode, with at least three prospective trials of APRV in acute respiratory distress syndrome (ARDS) currently underway (15-17). Clinical trials of APRV have, to date, been conducted primarily in the adult population $(12,18,19)$, with only a few pediatric reports in the literature (20). The experience with APRV in the neonatal and preterm populations is even more limited (21). The primary objective of the present retrospective study was to evaluate our experience and the feasibility of applying APRV in VLBW infants. Our secondary objective was to review the pediatric literature on APRV to better understand the current published experience, how this mode is currently being used in children, and the evidence of its efficacy and safety in this population.

\section{METHODS}

The present study was approved by the Research Ethics Board at McMaster University (Hamilton, Ontario). All VLBW infants admitted to the neonatal intensive care unit at McMaster Children's Hospital who were ventilated using APRV during a 24-month period were reviewed. APRV was delivered using the Servo-i ventilator (Maquet Medical Systems, USA). Data regarding baseline clinical status, initial APRV settings, their reported subsequent clinical course

${ }^{1}$ Department of Pediatrics; ${ }^{2}$ Department of Pediatrics, Division of Neonatology; ${ }^{3}$ Department of Pediatrics, Division of Pediatric Critical Care,

McMaster Children's Hospital; ${ }^{4}$ Department of Clinical Epidemiology and Biostatistics, McMaster University, Hamilton, Ontario

Correspondence: Dr Karen Choong, Department of Pediatrics and Critical Care, McMaster University, 1200 Main Street West, Room 3A-78,

Hamilton, Ontario L8N 325. Telephone 905-521-2100 ext 76651, fax 905-524-5707, e-mail choongk@mcmaster.ca 
TABLE 1

Summary of airway pressure release ventilation (APRV) indications, settings and clinical response

\begin{tabular}{|c|c|c|c|c|c|c|c|c|}
\hline Case & $\begin{array}{c}\text { Gestation, } \\
\text { weeks/birth } \\
\text { weight, } g \\
\end{array}$ & $\begin{array}{l}\text { Underlying } \\
\text { Diagnoses }\end{array}$ & Indication for APRV & $\begin{array}{c}\text { Age, days } \\
\text { weight, } g \text { at } \\
\text { start of APRV }\end{array}$ & $\begin{array}{l}\text { Ventilation } \\
\text { before APRV }\end{array}$ & $\begin{array}{l}\text { Initial APRV } \\
\text { settings }\end{array}$ & $\begin{array}{c}\text { Days on } \\
\text { APRV }\end{array}$ & $\begin{array}{l}\text { Clinical outcome } \\
\text { on APRV }\end{array}$ \\
\hline 1 & $26 / 810$ & $\begin{array}{l}\text { Severe chronic } \\
\text { lung disease, } \\
\text { past history of } \\
\text { pulmonary } \\
\text { hemorrhage } \\
\text { and air leak }\end{array}$ & Refractory hypoxemia & $130 / 3500$ & $\begin{array}{l}\mathrm{HFOV;} \mathrm{P}_{\mathrm{aw}} 26, \\
\text { delta } \mathrm{p} 31 \\
\text { frequency } \\
12 \mathrm{~Hz}, \mathrm{FiO}_{2} 0.8\end{array}$ & $\begin{array}{l}\mathrm{P}_{\text {high }} 26, \mathrm{P}_{\text {low }} 0, \\
\mathrm{~T}_{\text {high }} 2, \mathrm{~T}_{\text {low }} 0.2\end{array}$ & 3 & $\begin{array}{l}\text { Rapid improvement in } \\
\text { oxygenation. Muscle } \\
\text { relaxants discontinued } \\
\text { and sedatives weaned } \\
\text { while on APRV. No } \\
\text { adverse events }\end{array}$ \\
\hline 3 & $28 / 1230$ & $\begin{array}{l}\text { RDS, PPHN, } \\
\text { pneumo- } \\
\text { thoraces }\end{array}$ & $\begin{array}{l}\text { To facilitate } \\
\text { spontaneous } \\
\text { respiration, } \\
\text { minimize muscle } \\
\text { relaxant and } \\
\text { sedative use }\end{array}$ & $12 / 1130$ & $\begin{array}{l}\text { HFOV; delta } \mathrm{p} \\
\text { 18, frequency } \\
15 \mathrm{~Hz}, \mathrm{P}_{\text {aw }} 9 \\
\mathrm{FiO}_{2} 0.28 \\
\mathrm{NO}_{3} \text { ppm }\end{array}$ & $\begin{array}{l}\mathrm{P}_{\text {high }} 11, \mathrm{P}_{\text {low }} 0, \\
\mathrm{~T}_{\text {high }} 3, \mathrm{~T}_{\text {low }} 0.2\end{array}$ & 9 & $\begin{array}{l}\text { Muscle relaxants } \\
\text { discontinued on day of } \\
\text { change to APRV. } \\
\text { Sedatives successfully } \\
\text { weaned. Extubated from } \\
\text { APRV }\end{array}$ \\
\hline 4 & $24 / 620$ & $\begin{array}{l}\text { Chronic lung } \\
\text { disease }\end{array}$ & $\begin{array}{l}\text { Recurrent hypoxemic } \\
\text { and bradycardic } \\
\text { spells }\end{array}$ & $17 / 602$ & $\begin{array}{l}\text { SIMV PC 6, } \\
\text { PEEP 6, PS 7, } \\
\text { RR 40, } \\
\mathrm{FiO}_{2} 0.25\end{array}$ & $\begin{array}{l}\mathrm{P}_{\text {high }} 16, \mathrm{P}_{\text {low }} 2, \\
\mathrm{~T}_{\text {high }} 1.8, \mathrm{~T}_{\text {low }} 0.2\end{array}$ & 8 & $\begin{array}{l}\text { Significant improvement in } \\
\text { spells. Extubated from } \\
\text { APRV }\end{array}$ \\
\hline 5 & $24 / 680$ & $\begin{array}{l}\text { Chronic lung } \\
\text { disease }\end{array}$ & $\begin{array}{l}\text { Recurrent hypoxemic } \\
\text { and bradycardic } \\
\text { spells }\end{array}$ & $17 / 638$ & $\begin{array}{l}\text { SIMV PC 8, } \\
\text { PEEP 7, PS 8, } \\
\mathrm{P}_{\mathrm{aw}} 9, \mathrm{RR} 40, \\
\mathrm{FiO}_{2} 0.26\end{array}$ & $\begin{array}{l}\mathrm{P}_{\text {high }} 19, \mathrm{P}_{\text {low }} 2, \\
\mathrm{~T}_{\text {high }} 1.8, \mathrm{~T}_{\text {low }} 0.2\end{array}$ & 9 & $\begin{array}{l}\text { Significant improvement in } \\
\text { spells. Weaned to room } \\
\text { air in } 3 \mathrm{~h}\end{array}$ \\
\hline
\end{tabular}

APRV Airway pressure release ventilation; $\mathrm{FiO}_{2}$ Fraction of inspipred oxygen; HFOV High-frequency oscillatory ventilation; NO Nitric oxide; $P_{\text {aw }}$ Mean airway pressure $\left(\mathrm{cmH}_{2} \mathrm{O}\right) ; P C$ Pressure control (drive pressure) $\left(\mathrm{cmH}_{2} \mathrm{O}\right) ; \mathrm{PEEP}$ Positive end-expiratory pressure $\left(\mathrm{cmH}_{2} \mathrm{O}\right) ; P_{\text {high }}$ Distending airway pressure during inhalation; $P_{\text {low }}$ Distending airway pressure during exhalation; PPHN Persistent pulmonary hypertension; PS Pressure support ( $\left.\mathrm{cmH}_{2} \mathrm{O}\right)$; $R D S$ Respiratory distress syndrome; $R R$ Set respiratory rate (breaths/min); SIMV Synchronized intermittent mandatory ventilation; $T_{\text {high }}$ Duration of inhalation (s); $T_{\text {low }}$ Duration of exhalation (s)

and any recorded episodes of hemodynamic instability, air leaks or adverse events attributable to the use of APRV during this period were collected from each patient's health records (from physician, nurse and/or respiratory therapist notes). The PubMed, Embase and MEDLINE databases were searched for relevant articles published between January 1987 and December 2012 using the key words "airway pressure release ventilation", "APRV”, "pediatric" and "neonate”. Reference lists of primary articles and relevant reviews were manually searched, as were the following conference proceedings: Critical Care Congress, Critical Care Forum Canada, Society of Pediatric Research and European Society of Pediatric Research. Experimental and observational study designs as well as review articles were included, while studies conducted exclusively in adult populations were excluded. Two authors (SG and $\mathrm{KC}$ ) screened titles for relevance and abstracted fulltext articles for eligibility.

\section{Case series}

\section{RESULTS}

Of 812 invasively mechanically ventilated infants at McMaster Children's neonatal intensive care unit between January 2005 and December 2006, there were five VLBW patients who were ventilated using APRV: four males and one female, with birth weights ranging from $560 \mathrm{~g}$ to $1230 \mathrm{~g}$, and 24 to 28 weeks' gestational age (GA). APRV was initiated for a variety of reasons including: refractory hypoxemia despite high-frequency oscillatory ventilation (HFOV); ventilator dyssynchrony while on synchronized intermittent mechanical ventilation (SIMV); to facilitate spontaneous respiratory effort and reduce sedative use; and to alleviate severe apneic and bradycardic episodes despite full support on SIMV. These cases are described in detail below and summarized in Table 1.
Case 1: Female infant born at 26 weeks' GA with birth weight of $810 \mathrm{~g}$ with respiratory distress syndrome (RDS) requiring three doses of surfactant, who subsequently developed severe CLD requiring prolonged mechanical ventilation. Her early course was complicated by a pulmonary hemorrhage on day 2 and a pneumothorax on day 3 of life. Her respiratory status deteriorated on day 126, during which time HFOV was initiated. She was transitioned from HFOV to APRV because of persistent hypoxemia despite high fraction of inhaled oxygen $\left(\mathrm{FiO}_{2}\right)$ requirements. Following $3 \mathrm{~h}$ of $\mathrm{APRV}$, her $\mathrm{FiO}_{2}$ requirements improved from 0.8 to 0.55 , and was weaned further to 0.27 two days later. She remained on APRV for three days, was transitioned to conventional mechanical ventilation and successfully extubated on day 170 of life. She required high doses of neuromuscular blockade and continuous opioid infusion for sedation while on HFOV, both of which were discontinued on initiation of APRV and within $24 \mathrm{~h}$, respectively.

Case 2: Male infant born at 28 weeks' GA weighing $560 \mathrm{~g}$. He received a single dose of surfactant for RDS and was extubated from conventional mechanical ventilation to nasal continuous positive airway pressure by $48 \mathrm{~h}$ of life. On day 21 , he was reintubated for respiratory failure secondary to bacterial pneumonia and remained ventilator dependent for a prolonged period. He was switched from SIMV to APRV because of increased work of breathing and ventilator dyssynchrony. He tolerated APRV well in that he appeared comfortable, and did not require escalation in sedation nor neuromuscular blockade. He remained on APRV for 10 days, was switched to conventional mechanical ventilation and eventually extubated on day 102 of life. Case 3: Male infant born at 28 weeks' GA weighing $1230 \mathrm{~g}$ with RDS, persistent pulmonary hypertension and bilateral pneumothoraces, who required $\mathrm{HFOV}$ and inhaled nitric oxide from day 1 of life. He was 


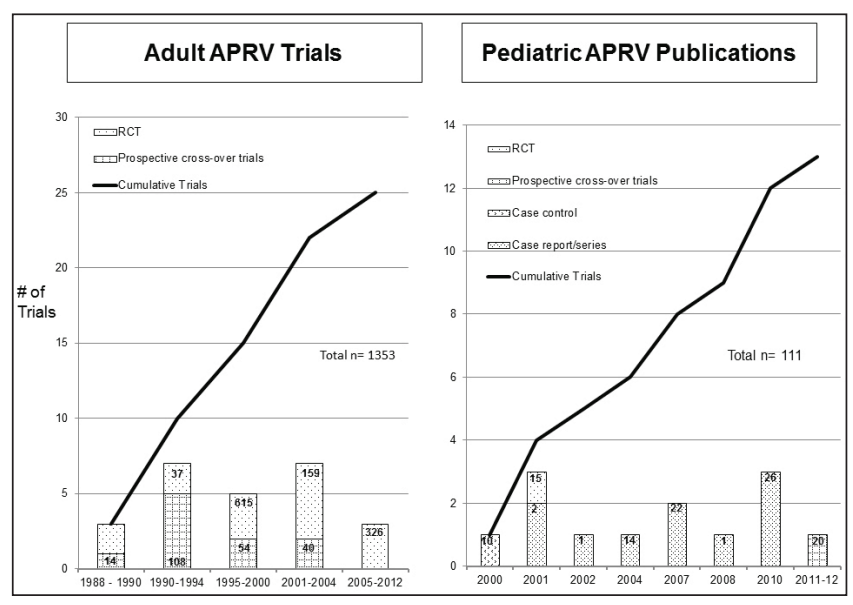

Figure 1) The adult airway pressure release ventilation (APRV) trials plots the number of prospective trials comparing APRV with conventional ventilation and total number of patients enrolled (presented in each bar) between 1988 and 2012. The pediatric APRV publications graphs total number of children studied and the types of pediatric studies published in each year to date. RCT Randomized controlled trial

switched from HFOV to APRV to facilitate spontaneous breathing and reduce requirements for neuromuscular blockade and continuous sedative infusions. He received a single dose of fentanyl during transition to APRV, following which muscle relaxants were discontinued, and his opioid infusion was successfully weaned off within $3 \mathrm{~h}$. Inhaled nitric oxide was also weaned off shortly after initiation of APRV. He was successfully extubated after nine days of APRV.

Cases 4 and 5: Twenty-four weeks' GA male twins with birth weights of $620 \mathrm{~g}$ (twin A) and $680 \mathrm{~g}$ (twin B). Both twins had RDS, and developed clinical and radiological evidence of bronchopulmonary dysplasia after the second week of life. Both infants experienced recurrent, frequent periods of oxygen desaturation and bradycardia despite full conventional ventilatory support and were, therefore, initiated on APRV on day 17 of life in an attempt to minimize hypoxemic episodes. Twin A's ventilation significantly improved following APRV (venous blood gas: $\mathrm{pH} 7.23, \mathrm{PCO}_{2} 71 \mathrm{mmHg}, \mathrm{PO}_{2} 22 \mathrm{mmHg}, \mathrm{HCO}_{3} 29 \mathrm{mmol} / \mathrm{L}$ on SIMV, to pH 7.51, $\mathrm{PCO}_{2} 38 \mathrm{mmHg}, \mathrm{PO}_{2} 28 \mathrm{mmHg}, \mathrm{HCO}_{3}$ $29 \mathrm{mmol} / \mathrm{L}$, base excess +6 on APRV). He was weaned to room air within $2 \mathrm{~h}$ of APRV, and the frequency and duration of hypoxemic episodes were noted to improve remarkably. Twin A was weaned and successfully extubated from APRV to room air seven days later. Twin B's ventilation also improved following APRV (venous blood gas: $\mathrm{pH}$ 7.27, $\mathrm{PCO}_{2} 60 \mathrm{mmHg}, \mathrm{PO}_{2} 31 \mathrm{mmHg}, \mathrm{HCO}_{3} 26 \mathrm{mmol} / \mathrm{L}$ on SIMV, to pH 7.37, $\mathrm{PCO}_{2} 51 \mathrm{mmHg}, \mathrm{PO}_{2} 19 \mathrm{mmHg}, \mathrm{HCO}_{3} 30 \mathrm{mmol} / \mathrm{L}$, base deficit -4 after 30 min of APRV). He was weaned to room air within $3 \mathrm{~h}$, and the episodes of desaturation and bradycardia were also noted to be significantly less frequent. Twin B was transitioned to SIMV after nine days of APRV, and successfully extubated five days later. There were no adverse events that occurred during APRV for either twin, and neither twin required any sedatives while they were on APRV.

There were no recorded episodes of hemodynamic instability, episodes of air leaks or adverse events attributable to the use of APRV in any of the five cases.

\section{Review of the pediatric literature}

The review of the literature revealed 13 pediatric studies conducted on a total of 111 children. Three of these studies involved neonates. In contrast, there have been more than 23 prospective adult trials enrolling >1350 patients since 1988 (Figure 1). The pediatric publications on APRV are summarized in Table 2 . All but three studies $(6,22,23)$ are retrospective case reports or case series of ARPV as a rescue ventilator mode in patients with refractory hypoxemic respiratory failure. These studies, described below, reported that following APRV, oxygenation and ventilation improved, hemodynamic status remained stable, and patients tolerated the change well with a reduction in sedation use and neuromuscular blockade. Mean airway pressure on APRV was either higher or no different than SIMV in studies that reported this outcome.

de Carvalho et al (22) conducted a case control study comparing three modes of ventilation (intermittent mandatory ventilation with positive end expiratory pressure, APRV and continuous positive airway pressure) in a cohort of postoperative cardiac children. They observed a significant increase in mean airway pressure with APRV, and no significant differences in oxygenation. Walsh et al (23) evaluated the effect of APRV compared with pressure-controlled ventilation in paralyzed and spontaneously breathing children following tetralogy of Fallot repair, cavopulmonary shunt or Fontan operations. In this prospective crossover study, they found no differences in lung perfusion or any of the measured gas exchange of hemodynamic parameters in the absence of spontaneous ventilation. However, during spontaneous ventilation, mean pulmonary blood flow and subsequently oxygen delivery increased significantly with APRV compared with pressure controlled ventilation. The authors concluded that spontaneous respiratory effort during APRV may divert ventilation toward areas of increased perfusion, and contraction of the diaphragm causes more posterior and dorsal lung segments, which have more dependent blood supply, to expand. To date, there has been only one prospective randomized controlled trial of APRV involving a pediatric population. Schultz et al (6) measured hemodynamic and respiratory parameters in children with acute lung injury or ARDS after stabilization on APRV and SIMV, respectively, and thereafter crossed subjects over to the other mode and repeated measurements. They found comparable levels of oxygenation, ventilation, hemodynamic measurements and patient comfort between APRV and SIMV.

The experience with APRV settings reported in the pediatric literature and the only published pediatric specific guidelines for APRV, as suggested by Habashi et al (5), are summarized in Table 3. Although these guidelines recommend lower initial $\mathrm{P}_{\text {high }}$ settings in the neonatal and pediatric population, the settings reported in clinical practice are variable and appear to approximate those recommended in adults.

\section{DISCUSSION}

While the evidence and experience with APRV in critically ill adults is steadily growing, with more than 20 prospective trials published since 1987, APRV use in children is relatively new, with the first report published in 2000 (22). As a result, APRV is presently infrequently used in children. A cross-sectional study of acute lung injury and ARDS conducted in 59 pediatric critical care units in 12 countries across North America and Europe revealed a frequency of APRV use of only $1.6 \%$ compared with $75.2 \%$ conventional mechanical ventilation, $16.4 \%$ HFOV and $8.5 \%$ noninvasive mechanical ventilation use (24). In contrast, $11.3 \%$ of adult ARDS patients are ventilated with APRV, and it appears that APRV use occurs more frequently in Europe than in North America (25). These statistical and geographical differences are not surprising given the current paucity of evidence regarding APRV in pediatric populations.

The current level of evidence with respect to APRV in pediatrics consists primarily of case reports or series, with only one prospective trial evaluating short-term cardiorespiratory outcomes (6). Our review of the literature indicates that while APRV appears to be used for a variety of indications, it is primarily a rescue mode in this population. The most common indications for APRV use in children according to the current literature are: a rescue mode in ARDS and refractory hypoxemia; hypoxemic spells associated with bronchopulmonary dysplasia; and to encourage ventilator synchrony and decrease the use of sedatives and neuromuscular blockade. The outcomes reported from these studies are variable, with some suggesting improvement in oxygenation and ventilation and a reduction in sedation, while others observing no change. The study by Walsh et al (23) suggests that spontaneous breathing during APRV may improve cardiopulmonary 
TABLE 2

Summary of pediatric publications on airway pressure release ventilation (APRV)

\begin{tabular}{|c|c|c|c|c|}
\hline Author (reference), year & Study design*; age & $\mathbf{n}$ & Indication for APRV & Main findings \\
\hline Walsh et al (23), 2011 & $\begin{array}{l}\text { Prospective crossover study } \\
\text { (APRV versus pressure control } \\
\text { ventilation); } 6-48 \text { months }\end{array}$ & 20 & $\begin{array}{l}\text { Tetralogy of Fallot repair, } \\
\text { cavopulmonary shunt, or } \\
\text { Fontan operation }\end{array}$ & $\begin{array}{l}\text { Improved pulmonary blood flow and oxygen delivery } \\
\text { with APRV compared with pressure control } \\
\text { ventilation }\end{array}$ \\
\hline Kamath et al (28), 2010 & Case series; $1-15$ years & 14 & Rescue therapy for ALI/ARDS & $\begin{array}{l}\text { No change in hemodynamics, urine output, } \\
\text { oxygenation, sedatives or neuromuscular blockers } \\
\text { post-APRV. Higher } \mathrm{P}_{\mathrm{aw}} \text { versus CMV }\end{array}$ \\
\hline Kuruma et al (29), 2008 & $\begin{array}{l}\text { Case report; 10-month-old } \\
\text { postrenal transplant }\end{array}$ & 1 & $\begin{array}{l}\text { Rescue; intraoperative hypoxemia } \\
\text { and hemodynamic instability }\end{array}$ & $\begin{array}{l}\text { Improved oxygenation, stable hemodynamics, } \\
\text { extubated } 2 \text { days later }\end{array}$ \\
\hline Garcia et al (30), 2007 & $\begin{array}{l}\text { Case series; } 1 \text { day }-7 \text { months, } \\
24-40 \text { weeks' gestational age } \\
\text { at birth }\end{array}$ & 15 & 'Proactive', or rescue & $\begin{array}{l}\text { Improved gas exchange with proactive APRV; } 56 \% \\
\text { overall mortality rate, } 75 \% \text { mortality with rescue }\end{array}$ \\
\hline Hales et al (31), 2002 & $\begin{array}{l}\text { Case report; } 9 \text { month ex-30 } \\
\text { week premature infant }\end{array}$ & 1 & $\begin{array}{l}\text { Rescue therapy, aspiration } \\
\text { pneumonitis and ARDS }\end{array}$ & Sedation and paralysis discontinued on APRV \\
\hline Varpula et al (14), 2001 & Case report; 13-year-old & 1 & $\begin{array}{l}\text { Rescue therapy; APRV + prone } \\
\text { positioning in trauma patient }\end{array}$ & Prone position is feasible with APRV \\
\hline Foland et al (32), 2001 & Case report; 2.5 -year-old & 1 & Rescue therapy for ARDS & Improved oxygenation and ventilation \\
\hline Schultz et al (6), 2001 & $\begin{array}{l}\text { Prospective, randomized cross- } \\
\text { over trial of APRV and SIMV; } \\
1-15 \text { years }\end{array}$ & 15 & $\begin{array}{l}\text { Mechanical ventilation }<7 \text { days, } \\
\leq 8 \mathrm{~kg}\end{array}$ & $\begin{array}{l}\text { Significantly lower PIP and } \mathrm{P}_{\text {plat }} \text { with APRV. No } \\
\text { differences in } \mathrm{P}_{\mathrm{aw}} \text { or hemodynamic variables }\end{array}$ \\
\hline $\begin{array}{l}\text { de Carvalho et al (22), } \\
2000\end{array}$ & $\begin{array}{l}\text { Prospective case control (post- } \\
\text { operative cardiac surgery); } \\
7 \text { months }-7 \text { years }\end{array}$ & 10 & $\begin{array}{l}\text { Postoperative cardiac surgery with } \\
\text { pulmonary hypertension and } \\
\text { airspace disease }\end{array}$ & $\begin{array}{l}\text { No changes in oxygenation. Higher } \mathrm{P}_{\mathrm{aw}} \text { and CVP, } \\
\text { no respiratory or hemodynamic adverse effects }\end{array}$ \\
\hline
\end{tabular}

*All studies were retrospective in design unless otherwise indicated. ALI Acute lung injury; ARDS Acute respiratory distress syndrome; CMV Conventional mechanical ventilation; CVP Central venous pressure; $P_{\text {aw }}$ Mean airway pressure; PIP Peak inspiratory pressure; $P_{\text {plat }}$ Plateau pressure; SIMV Synchronized intermittent mechanical ventilation

TABLE 3

Comparison of current pediatric guidelines and published clinical experience in setting airway pressure release ventilation

\begin{tabular}{|c|c|c|c|c|c|}
\hline & \multicolumn{2}{|c|}{ Guidelines* } & \multicolumn{2}{|c|}{$\begin{array}{l}\text { Experience from pediatric } \\
\text { publications }^{\dagger}\end{array}$} & \multirow[b]{2}{*}{ Considerations } \\
\hline & Pediatric & Neonate & Pediatric & Neonate & \\
\hline $\mathrm{P}_{\mathrm{High}}, \mathrm{cmH}_{2} \mathrm{O}$ & $20-30$ & $10-25$ & $24-43$ & $22-38$ & $\begin{array}{l}\text { Guidelines: "Use lower } \mathrm{P}_{\text {high }} \text { than adults as chest wall more compliant. Higher } \\
\mathrm{P}_{\text {high }} \text { may be necessary in patients with decreased thoracic/abdominal } \\
\text { compliance, or morbid obesity." }\end{array}$ \\
\hline $\mathrm{T}_{\text {High }}, \mathrm{S}$ & $3-5$ & $2-3$ & $2-5.5$ & $3-5 ; 1.8-3$ & Guidelines: "Use slightly shorter $\mathrm{T}_{\text {high }}$ than adults." \\
\hline $\mathrm{T}_{\text {Low }}, \mathrm{S}$ & $0.2-0.8$ & $0.2-0.4$ & $0.4-0.6$ & $0.2-0.8$ & $\begin{array}{l}\text { Guidelines: "Use slightly shorter } \mathrm{T}_{\text {low }} \text { than adults as shorter time constants in } \\
\text { this population. Aim for } 50 \% \text { to } 75 \% \text { of peak expiratory gas flow as end point." }\end{array}$ \\
\hline $\mathrm{P}_{\text {Low }}, \mathrm{cmH}_{2} \mathrm{O}$ & 0 & 0 & $0-3, \max 10$ & $0-5$ & $\begin{array}{l}\text { Guidelines: "Use } \mathrm{P}_{\text {low }}=0 \text { as accelerates peak expiratory flow rate." }{ }^{\dagger} \text { Pediatric } \\
\text { experience: Use } \mathrm{P}_{\text {low }}>0 \text { to prevent alveolar derecruitment and overcome the } \\
\text { limitation posed by current commercially available ventilators on setting } \mathrm{T}_{\text {low" }}\end{array}$ \\
\hline
\end{tabular}

${ }^{\star}$ Based on the clinical guide published by Habashi (5). The ranges presented in these guidelines are listed as those typically required in each age group; ${ }^{\dagger}$ Pediatric experience collated from the airway pressure release publications presented in Table 2. $P_{\text {high }}$ Distending airway pressure during inhalation; $P_{\text {low }}$ Distending airway pressure during exhalation; $T_{\text {high }}$ Duration of inhalation; $T_{\text {low }}$ Duration of exhalation

interactions and may, therefore, be beneficial in patients in whom hemodynamics and pulmonary blood flow is impaired by positive pressure ventilation. Although it is proposed that APRV may reduce airway pressure requirements compared with conventional ventilation, this is not substantiated by the evidence to date. The potential for adverse sequelae should also be recognized, particularly when this mode is infrequently used; improvements in ventilation with APRV may lead to rapid changes in $\mathrm{PaCO}_{2}, \mathrm{pH}$, intrathoracic pressure and, subsequently, cerebral blood-flow velocity fluctuations in the vulnerable premature neonate.
Our case series of APRV use in five VLBW infants adds to the growing body of literature supporting this method of ventilation as a feasible, elective and a rescue mode in this population. However, we acknowledge the possible reporting and ascertainment biases with respect to clinical and adverse event outcomes inherent in a retrospective study. While preliminary studies suggest that infants and children tolerate APRV with no reported adverse events, one cannot conclude that this mode of open-lung ventilation is more efficacious than either conventional ventilation or HFOV due to the paucity and low grade of evidence. 
There is clearly a learning curve associated with the pediatric APRV experience. We observed a variation and deviation in how APRV is used in this population from the original pediatric guidelines recommended by Habashi (5). These guidelines were empirically derived from limited evidence and largely extrapolated from the adult literature, and may not have taken into consideration the wide variety of conditions, age and size of patients encountered in the pediatric and neonatal setting. APRV settings, particularly when used in a rescue mode, can approximate those used in the adult population. While the Habashi (5) guidelines are useful as a starting point, patient condition and disease process ultimately determines how APRV is titrated. Although these guidelines recommend a $\mathrm{P}_{\text {low }}$ of zero, our experience with APRV in VLBW infants suggests that small infants and neonates often require a $\mathrm{P}_{\text {low }}>0$ to prevent alveolar collapse. Preventing derecruitment during APRV is a function of both $\mathrm{P}_{\text {low }}$ and $\mathrm{T}_{\text {low }} \mathrm{T}_{\text {low }}$ is ideally determined by monitoring the expiratory flow time waveform, and targeting $\mathrm{T}_{\text {low }}$ between $50 \%$ and $75 \%$ of the peak expiratory flow. However, because time constants are shorter in infants with acute lung injury, the $\mathrm{T}_{\text {low }}$ should be adjusted accordingly to maintain an adequate level of intrinsic positive end-expiratory pressure, and subsequent physiological dynamic hyperinflation above resting lung volume. Appropriate $\mathrm{T}_{\text {low }}$ may, therefore, be difficult to set in this population because current commercially available ventilators (such as the Servo-I, Dräger Evita and Avea, USA), have a minimum $\mathrm{T}_{\text {low }}$ limit of $0.2 \mathrm{~s}$, and only allow $\mathrm{T}_{\text {low }}$ to be set in $0.1 \mathrm{~s}$ increments. To overcome this limitation, we suggest setting $\mathrm{P}_{\text {low }}>0$. This practice appears to be supported by the published pediatric experience to date $(14,21)$. It is also important to consider the unique features of the particular ventilator and the compliance of the ventilator circuit when establishing APRV (26). Most current ventilators have a universal platform, and setting APRV is targeted more toward adults than the pediatric or neonatal population. A newer ventilator specific for neonates, the Evita Infinity V500 (Dräger, USA). allows the $T_{\text {low }}$ to be set in $0.01 \mathrm{~s}$ increments, with a lower limit of $0.05 \mathrm{~s}$.

\section{REFERENCES}

1. Clark RH, Gerstmann DR, Jobe AH, Moffitt ST, Slutsky AS, Yoder BA. Lung injury in neonates: Causes, strategies for prevention, and long-term consequences. J Pediatr 2001;139:478-86.

2. Lemons J, Bauer C, Oh W, et al. Very low birth weight outcomes of the National Institute of Child Health and Human Development Neonatal Research Network, January 1995 through December 1996. Pediatrics 2001;107:e1.

3. Philip AG. Oxygen plus pressure plus time: The etiology of bronchopulmonary dysplasia. Pediatrics 1975;55:44-50.

4. Stock MC, Downs JB, Frolicher DA. Airway pressure release ventilation. Crit Care Med 1987;15:462-6.

5. Habashi NM. Other approaches to open-lung ventilation: Airway pressure release ventilation. Crit Care Med 2005;33:S228-40.

6. Schultz TR, Costarino AT, Duming SM, et al. Airway pressure release ventilation in pediatrics. Pediatr Crit Care Med 2001;2:243-6.

7. Downs JB, Stock MC. Airway pressure release ventilation: A new concept in ventilatory support. Crit Care Med 1987;15:459-61.

8. Sydow M, Burchardi H, Ephraim E, Zielmann S, Crozier TA. Long-term effects of two different ventilatory modes on oxygenation in acute lung injury. Comparison of airway pressure release ventilation and volume-controlled inverse ratio ventilation. Am J Respir Crit Care Med 1994;149:1550-6.

9. Putensen C, Zech S, Wrigge H, et al. Long-term effects of spontaneous breathing during ventilatory support in patients with acute lung injury. Am J Respir Crit Care Med 2001;164:43-9.

10. Wrigge H, Zinserling J, Neumann P, et al. Spontaneous breathing improves lung aeration in oleic-acid injury lung injury. Anesthesiology 2003;99:376-84.

11. Putensen C, Mutz N, Putensen-Himmer G, Zinserling J. Spontaneous breathing during ventilatory support improves ventilation-perfusion distributions in patients with acute respiratory distress syndrome. Am J Respir Crit Care Med 1999;159:1241-8.

\section{CONCLUSION}

APRV is a novel mode of ventilation with proposed advantages over conventional and high-frequency ventilation, but with very limited experience in pediatric and newborn populations. There are some unique and important considerations that require re-evaluation of the original guidelines when applying APRV in small infants, particularly when setting the $\mathrm{P}_{\text {low }}$. Although there is growing enthusiasm for this mode of ventilation in pediatric patients with ARDS and adverse cardiopulmonary interactions, as with any novel intervention, further clinical experience and research is essential - particularly because this technology is evolving - to understand how best to apply this mode of ventilation in the pediatric population with its diverse indications and disease processes, and identify which patients may benefit. Until such time, the concept of such a ventilation mode should encourage us to consider how best to achieve open and protective lung ventilation strategies using the currently accessible, time-tested and evidencebased tools available to us.

DISCLOSURES: The authors have no financial disclosures or conflicts of interest to declare.

ACKNOWLEDGEMENTS: S Gupta and K Choong had full access to all of the data in the study and take responsibility for the integrity of the data and the accuracy of the data analysis. Specific author contributions are as follows: Study concept and design: K Choong, S Gupta, V Joshi, P Joshi; Acquisition of data: K Choong, S Gupta, V Joshi, P Joshi; Analysis and interpretation of data: K Choong, S Gupta, V Joshi; Drafting of manuscript: K Choong, S Gupta, V Joshi; Statistical analysis: N/A; Critical revision of the manuscript for important intellectual content: K Choong, S Gupta, V Joshi, P Joshi, S Monkman, K Vallaincourt; Approval of submitted and final versions: K Choong, S Gupta, V Joshi, P Joshi, S Monkman, K Vallaincourt; Administrative, technical, or material support: K Choong; Study supervision: K Choong.
12. Davis KJ, Johnson DJ, Branson RD, Campbell RS, Johannigman JA, Porembka D. Airway pressure release ventilation.

Arch Surg 1993;128:1348-52.

13. Rasanen J, Downs JB, Stock MC. Cardiovascular effects of conventional positive pressure ventilation and airway pressure release ventilation. Chest 1988;93:911-5.

14. Varpula T, Pettila V, Nieminen H, Takkunen O. Airway pressure release ventilation and prone positioning in severe acute respiratory distress syndrome. Acta Anaesthesiol Scand 2001;45:340-4.

15. Brower R, Britos M. Airway Pressure Research Ventilation in Acute Lung Injury. ClinicalTrialsgov NCT00750204.

16. Kyle W, Shah J, Fraire E, Laeser M, Boldt J Jr, Tumlin J. APRV vs. ARDSnet protocol ventilation for ARDS/ALI. Am J Respir Crit Care Med 2010;181:A1691.

17. Tumlin J. Airway Pressure Research Ventilation (APRV) compared to ARDSnet Ventilation PRESSURE. ClinicalTrialsgov NCT0093013.

18. Garner W, Downs JB, Stock MC, Rasanen J. Airway pressure release ventilation (APRV). A human trial. Chest 1988;94:779-81.

19. Rathgeber J, Schorn B, Falk V, Kazmaler S, Spiegel T, Burchardi H. The influence of controlled mandatory ventilation (CMV), intermittent mandatory ventilation (IMV) and biphasic intermittent positive airway pressure (BIPAP) on duration of intubation and consumption of analgesics and sedatives. A prospective analysis in 596 patients following adult cardiac surgery. Eur J Anaesthesiol 1997;14:576-82.

20. Krishnan J, Morrison W. Airway pressure release ventilation: A pediatric case series. Pediatr Pulmonol 2007;42:83-8.

21. Kelly L, Alagarsamy S, Tostado A, Klein G, Seri I. Feasibility of airway pressure release ventilation in infants with near end stageneonatal bronchopulmonary dysplasia. J Neonatal Perinatal Med 2010;3:171-5. 
22. de Carvalho W, Kopelman B, Gurgueira G, Bonassa J. Airway pressure release in postoperative cardiac surgery in pediatric patients. Rev Assoc Med Bras 2000;46:166-73.

23. Walsh M, Merat M, La Rotta G, et al. Airway pressure release ventilation improves pulmonary blood flow in infants after cardiac surgery. Crit Care Med 2011;39:2599-604.

24. Santschi M, Jouvet P, Leclerc F, et al. Acute lung injury in children: Therapeutic practice and feasibility of international clinical trials. Pediatr Crit Care Med 2010;11:681-9.

25. Gonzalez M, Arroliga AC, Frutos-Vivar F, et al. Airway pressure release ventilation versus assist-control ventilation: A comparative propensity score and international cohort study. Intens Care Med 2010;36:817-27.

26. Seymour C, Frazer M, Reilly P, Fuchs B. Airway pressure release and biphasic intermittent positive airway pressure ventilation: Are they ready for prime time? J Trauma Injury Infect Crit Care 2007;62:1298-309.

27. Demirkol D, Karabocuoglu M, Citak A. Airway pressure release ventilation: An alternative ventilation mode for pediatric acute hypoxemic respiratory failure. Indian J Pediatr 2010;77:1322-25.
28. Kamath S, Super D, Mhanna M. Effects of airway pressure release ventilation on blood pressure and urine output in children. Pediatr Pulmonol 2010;45:48-54.

29. Kuruma Y, Hirasaki Y, Taniguchi Y, et al. Airway pressure release ventilation for respiratory management in a pediatric case after adult-size kidney transplantation. Pediatr Anaesth 2008;18:1271-2.

30. Garcia P, Henry J, Hughes S, Boylan C. A case series of infants on APRV in the neonatal ICU. Respir Care, Open Forum Abstract. 2007.

31. Hales R, Durning S, Bonn K, Nadkarni V. Early intervention with HFOV and APRV for a pediatric patient with aspiration pneumonitis: A case study. Respir Care, Open Forum Abstract, 2002.

32. Foland J, Martin J, Novotny T, Super D, Dyer R, Mhanna M. Airway pressure release ventilation with a short release time in a child with acute respiratory distress syndrome. Respir Care 2001;46:1019-23. 


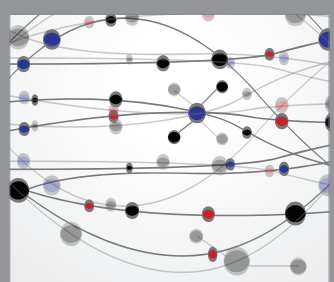

The Scientific World Journal
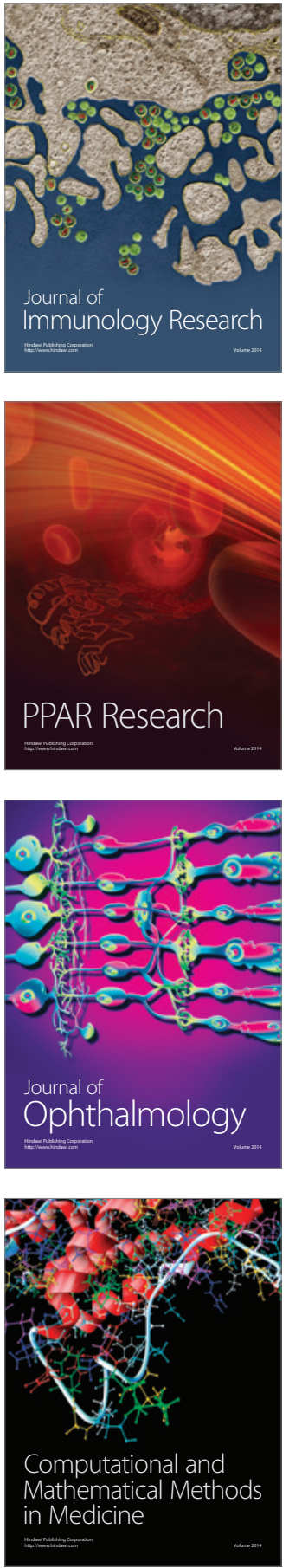

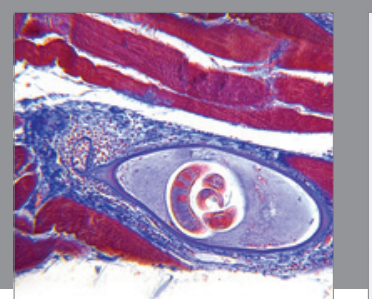

Gastroenterology Research and Practice

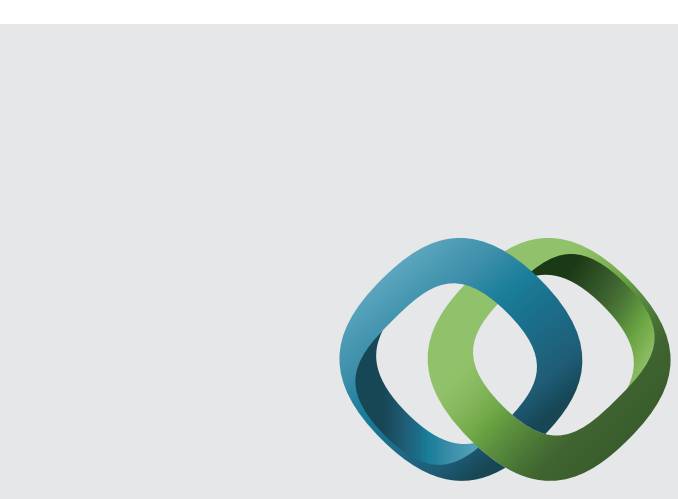

\section{Hindawi}

Submit your manuscripts at

http://www.hindawi.com
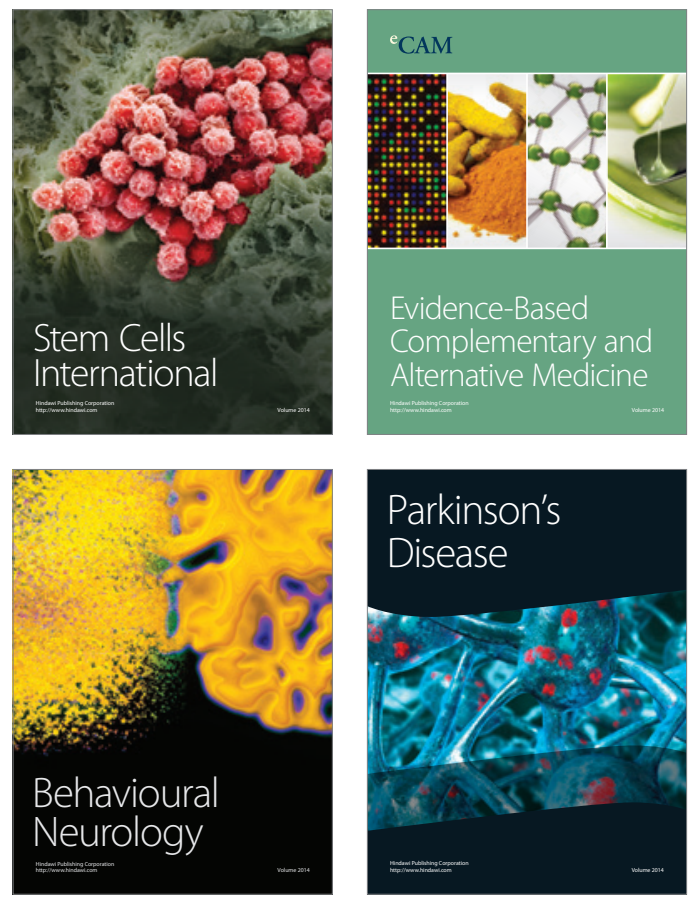
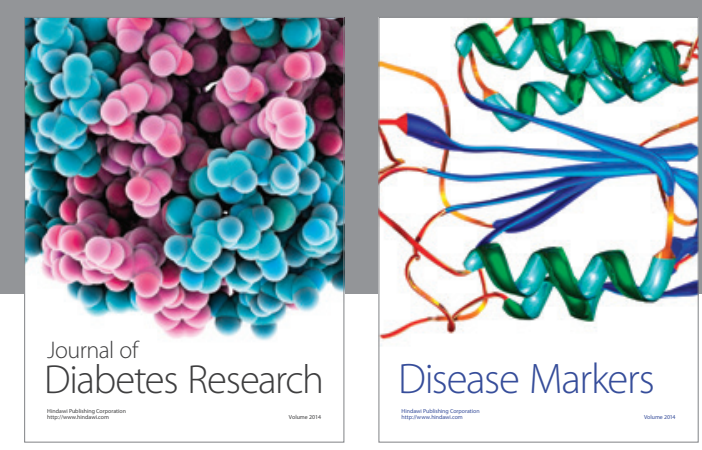

Disease Markers
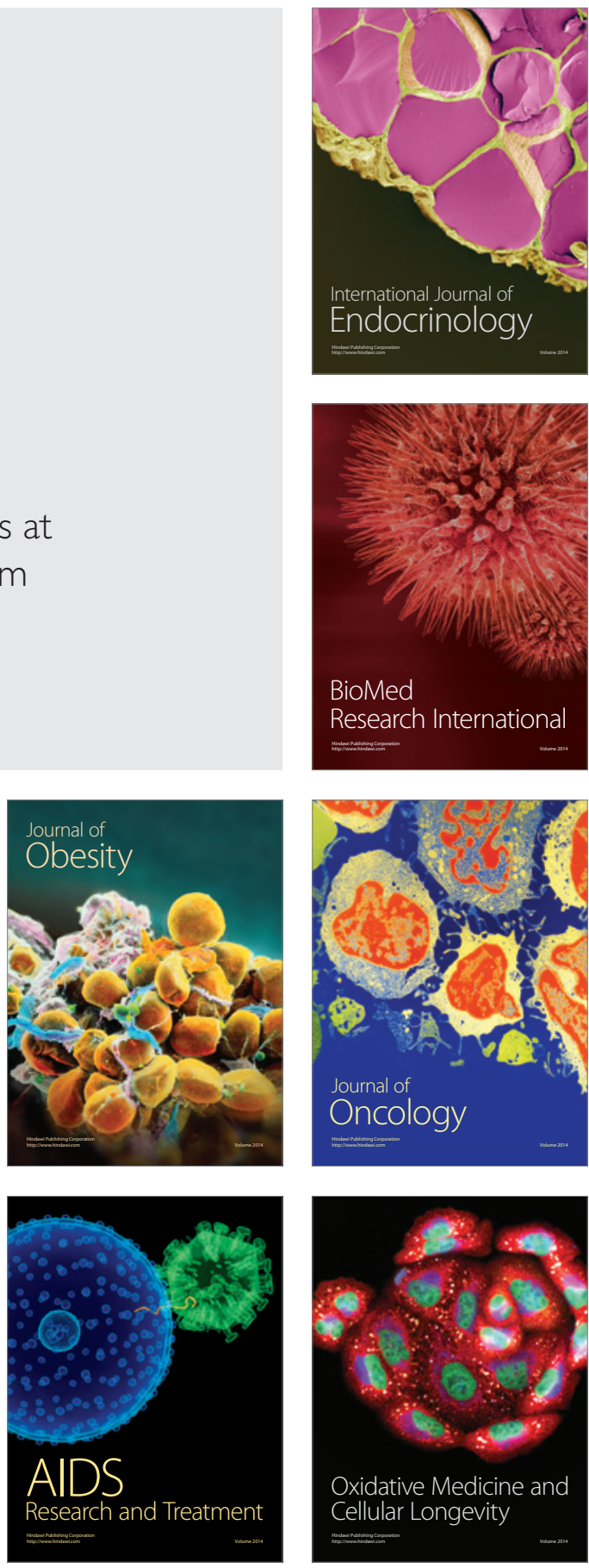